\title{
Mother Tongue As a Symbol Of Identity Within Biolinguistics Diversity In Denpasar
}

\author{
I Made Suastra ${ }^{*}$, Luh Putu Laksminy ${ }^{2}$, Gede Primahadi Wijaya Rajeg ${ }^{3}$ \\ English Department, Faculty of Humanities, Udayana University. Bali, Indonesia ${ }^{1}$ \\ English Depatment, Faculty of Humanities, Udayana University. Bali, Indonesia ${ }^{2}$ \\ English Depatment, Faculty of Humanities, Udayana University. Bali , Indonesia ${ }^{3}$ \\ \{madesuastra@yahoo.co.id ${ }^{1}$, made suastra@unud.ac.id ${ }^{2}$, luhputulaksminy@gmail.com ${ }^{3}$, \\ primahadiwijaya@gmail.com ${ }^{4}$
}

\begin{abstract}
This is a biolinguistic diversity study in multilingual communities. If a language is not acquired, mastered, and used from birth, the language is very likely to be classified as an endangered language. This study focuses on the status of Balinese as a mother tongue within multilingual communities in Denpasar city. The study aims at: 1) analysing the level of mastery of Balinese at the age of transitional period, 2) determining the status of Balinese as mother tongue, and 3) investigating the use of Balinese as the language of instruction in schools. This study used mixed methods. Data were analysed by using both quantitative and qualitative methods by applying sequential explanatory strategy. The theory of mother tongue (Calvet 2006), multilingual society (Romaine 1989) and language mastery (Holmes 2001) were applied as a basic framework of the study. The result of the study shows that the status of Balinese language in Denpasar city is no longer as the mother tongue. Consequently, the existence of Balinese has been in the position between vulnerable/unsafe and definitely endangered. However, children during the age of transitional period are very aware of the importance of language as one of Balinese ethnic identities. Therefore, they were encouraged to absorb and learn for a highly level of mastery of the Balinese language, which has a strong support from both individuals and social institutions but not from school, in order to avoid a more severe threat of Balinese language in the future.
\end{abstract}

Keywords: Language diversity; language endangered; mother tongue; language mastery

\section{Introduction}

This study concerns with a diversity of bio-linguistics in multilingual societies in which it is a strategic and political step linguistically towards language endangered. If a language is not acquired, mastered, and used from birth, the language is very likely to be classified as an "endangered language" or a language that is considered as the beginning of its existence to suffer from the treat. This study focuses on the status of Balinese as the mother tongue within multilingual communities in Denpasar city. UNESCO declared "International Mother 
Language Day" on 7 November $1999(30 \mathrm{c} / 62)$ and February $21^{\text {st }}$ is used as a milestone in the implementation of its activities. Suastra, et al. (2017) states that this prestigious institution issued a statement to give serious attention to the various culture diversity and language diversity/multilingualism, especially languages that are experiencing the threat of declining in use. Base on this situation, the study aims at: 1) analysing the level of mastery of Balinese in children at the age of transitional period as everyday language, 2) determining the status of Balinese whether as mother tongue/first language or second language and 3) investigating the use of Balinese as the language of instruction in schools.

The theoretical framework is based on the impact on the position of Balinese as the mother tongue. It is the language which is acquired before any other language is learned by the child. In other words, children acquire language naturally and automatically from birth (Khati 2011). Mother tongue is actually very important in the development of personal, social and cultural identity of the children because mother tongue can express moral values, virtues, traditions and identity of a culture.

A language can be said to be endangered if it is approaching the risk of being no longer used as a daily conversation by its speakers. There are several factors that cause this tendency, among others: speakers switch to another language; the speakers' hesitation in using their language; language is not inherited properly; decreased number of speakers; implementation of language domination (in education and media); ethnic cleansing/war; and the political pressure associated with language policy (UNESCO, 2003)

UNESCO (2003) classifies 6 levels of language endangered based on its inheritance strategy: Safe, Unsafe/Vulnerable, Definitely endangered, Severely endangered, Critically endangered and Extinct (see also Salminen, 1999).

Language is one of many components used to identify a person or group's identity (Wienreich, 1986). He explains that identity is the construction of personalities attached to a person or group to distinguish them from others. By showing linguistic characteristics, it will be easy to know the identity of the person. It can be said that language is one of ethnic identity symbols to express moral values, virtues, traditions and identity of a culture.

Language is basically more than just a means of communication, but also a means of selfexpression. Nowadays, education in Indonesia used Indonesian widely as the language of instruction at school. What equally important is the educators' attention on the awareness of using regional languages as the language of instruction in schools in accordance with the applicability of laws and regulations (Law of the Republic of Indonesia No. 20 of 2003 concerning the National Education System, article 33 paragraph (1 and 2) and the Presidential Decree of the Republic of Indonesia No. 63 of 2019 concerning the Use of Indonesian Language, article (3) paragraph (1).

\section{Method}

This research used a mixed method of quantitative and qualitative by applying sequential explanatory strategy (Creswell, 2009).The main data were obtained through surveys, observation, and interviews. This research was conducted in Denpasar which was divided into four regions, i.e. East, West, South, and North Denpasar. Sources of data in this study are oral and written data. The primary data in the forms of written data were the result of observations and surveys while oral data were collected from interviews. The population of this study was elementary school students in grade 5 and 6 . This group of students are classified as an adolescence which is considered as the age of critical period or Transitional period (Piaget, 
1972). In addition, the children at the age of 10 years and over have already possessed a complete and permanent structure of speech tools so that it will be easier to observe their mastery of their mother tongue and second language (Fry 1979; Chomsky 1965). The purposive sampling was applied to determine the respondents according to the objectives to be achieved in this research. The number of respondents were 50 students for each district, with a total of 200 respondents. The data taken from the respondents (students and teachers) were written data (survey) regarding the level of mastery of the Balinese language of the children; check list (observation) about the use of Balinese language between Balinese students at school; and recordings of conversations between Balinese ethnic students. Meanwhile, the data from the respondents (teachers) were taken from the surveys and interviews with the teachers who taught in grade 5 and 6 at selected elementary schools, that was about the use of Balinese as the language of instruction in schools. Secondary data of this research were sociolinguistic survey results and information about situation of language, culture and traditions of Balinese society nowadays. Because of the Covid-19 pandemic situation, all surveys were carried out online applying Google form and interviews using cell phone/telephone facilities and conversations were still carried out face-to-face. The data then analyzed quantitatively and qualitatively.

\section{Result and Discussion}

This section discusses the results of research conducted in multilingual communities in Denpasar city. The discussion starts with the Balinese language conditions of the age after early childhood which is called the transitional period, followed by a discussion of mastery of Balinese in transitional age, the sources of acquisition of the Balinese language, language policy, and the status of the Balinese language as an identity.

\subsection{Language Conditions of Children at the Age of Transitional Period.}

Massive children's language development occurs at an early age, the higher the age, the more linguistic level of language development will decrease. This condition can be understood because biologically the structure of the children's speech aparatus is getting permanent. According to Piaget (1972), children at the age around 7 to 11 years are classified into the "concrete operational period", where the children cognitively undergo a critical period. The child experiences the process of cognitive development from childhood to adolescence from a less logical way of thinking to a logical thinking process. The results of research on the Balinese language in transitional period children show that children's language development is greatly influenced by the child's environment, especially at home, school and circle of friends. At first the children absorbed words, and with the development of these vocabularies, they learn to master simple sentences to more complete sentences. In addition, children also begin to develop in the level of "meta linguistic awareness" that children begin to understand the context of the language they use.

\subsection{Mastery of Balinese Language during Transitional Period}

The results of this study strongly support the previous finding (Suastra et al., 2019) that early age of Balinese ethnic children living in the urban area of Denpasar did not acquire the Balinese language from birth. The data shows that $71 \%$ of children during the transitional period (around 10-12 years of age) acquired Indonesian from birth. However, In relation to the mastery of Balinese in this age indicates a contradictory result with the fact that children 
during this transitional period can master Balinese fluently. The data shows that $78.9 \%$ of children during this age master Balinese language. The results also show a fairly good frequency $(58.7 \%)$ to the use of Balinese in the family domain. The finding of this study can dispel our constant worries of the indications of the threat to the Balinese language toward endangered even though it is not as the first language.

The sources of the acquisition and absorption of a language are very important in language mastery. There are two learning sources in this conditions namely; individual and institutional resources. Individually, parents are becoming the main source for the children to absorb and acquire Balinese language $(81.9 \%)$ followed by the teacher $(10.8 \%)$, playmates $(5.4 \%)$, relatives $(1.5 \%)$ and the media at $(0.4 \%)$. From this finding it can be interpreted that one of the sources of learning for children at this age apart from their parents at home is the school's teachers. Institutionally, the family is still the main source for children during this age (83.4\%) compare to other institutions such as school (7.7\%), environment $(6.9 \%)$, and other communities (only $1.9 \%$ ) respectively.

In term of the use of Balinese as a language of instruction at school related to the article (3) of the Presidential Decree of Republic of Indonesia No. 63 of 2019 which allows regional languages to be used as the language of instruction in primary schools in the first and second year, it seems that the regulations concerning language policy in education were not well understood by teachers. Data on the understanding of this regulation shows that $95.7 \%$ of the teachers did not know that Balinese can be used as a language of instruction other than Indonesian from grade one to grade two in the learning process in elementary schools. This shows the inability of the teachers to understand language policies in education. This gives an implication that Balinese language had never been used as the language of instruction in learning from grade one to grade two in elementary schools. Consequently, there is no support from the school in maintaining and preserving Balinese as the children's mother tongue.

\subsection{Status of Balinese Language in Multilingual Society in Denpasar}

Observing the results of the above study and examining the results of previous studies, there is a phenomenon about the status of Balinese language in multilingual communities in Denpasar City. The results of Suastra's research (2019) show a tendency for Balinese to no longer be the mother tongue because children at the early age in Denpasar City did not acquire Balinese as their first language, in which the language should basically be acquired and used from birth. Examining this position of the Balinese language, it can be said that the Balinese language has already been in the position between Vulnerable (potentially endangered) to critically endangered (UNESCO, 2003; Khati, 2011). On the other hand, the results of this research show a consistent frequency of the children's mastery and use of Balinese language during transitional period. It can be said that the status of Balinese at the present time is not as children's first language or as mother tongue by definition, but the higher the level of cognitive development of children, the more the level of children's critical thinking (Piaget 1972) in determining an identity for themselves. In this study, this condition is referred as a "meta language and culture awareness" that is the awareness of the importance of language and culture as an identity. In this transitional period, children themselves begin to realize the existence of Balinese language as a symbol of both individual and social identity. Therefore, children during this age attempt to learn Balinese and at the same time use it in daily conversation. The example of child's conversation below strengthens the above analysis that in children of this age, Balinese is used as a daily conversation in the family, friendship and school environment.

Data 3. Conversation 2. (Minute 04.18) 
Conversation between elementary school children grade V in East Denpasar

A: men de? Engken gen

"What are you doing now"

B: melajah jumah tapi bagun tetep jam pitu keto..

"I am only studying at home but I still got up at seven"

A: dadi keto?

"Why"

B: pang ngenah je care masuk.... masuk biase keto............muride absene jak gurue.

"As if we are at school......like at school...the teacher checked the students' attendance"

A: video call.. keto

"Using video call...is it?"

B: sing ngabsen....absen gen, nganggon baju sekolah, nganggon dasi, nganggon rok.. keto.....

"No. Just for the record of our attendance, we wear costume, tie and skirt."

In the conversation, the children easily understand what is being asked and can give reaction communicatively. There are no difficulties for children to understand each other about the message they want to convey through Balinese so that communication can run smoothly. This proves that even though Balinese is not the mother tongue of the children, it is still believed by speakers' future generations as a symbol of Balinese ethnic identity.

\section{Conclusion}

Examining the discussion related to the status of Balinese in multilingual societies in Denpasar city above, it can be concluded as follows:

1. Although the results of this study on children of transitional period strengthen the previous finding that children did not acquire the Balinese language from birth, language mastery and language used by the children at this age show clear differences. Children at this age can speak Balinese fluently in conversation. This is supported by individual and institutional sources.

2. In terms of language policy, most of the teachers do not understand the regulations regarding the use of regional languages as the language of instruction in the field of education.

3. The status and position of the Balinese language in the multilingual community in Denpasar city is no longer as the mother tongue. However, children during this transitional period are very aware of the importance of the language as one of Balinese ethnic identities. Therefore, they make an effort to master and absorb the language which is supported by their parents, teachers, siblings and playmates. This is an attempt to avoid more severe threats of Balinese language toward endangered in the future.

\section{References}

[1] Brown, H. Douglas. 2000. Principles of Language Learning and Teaching. San Fransisco: Longman. 
[2] Brunner, Jerome. 1966. Learning about Learning. Washington D.C. U.S Government Printing Office.

[3] Calvet, Jouis Jean. 2006. Toward an Ecology of World Languages: Polity Press

[4] Chomsky, Noam. 1965. Aspects of the Theory of Syntax. Cambridge: MIT Press.

[5] Creswell, John .W. 2009. Research Design. Qualitative, Quantitative, and Mixed Methods Approaches. Singapore: SAGE Publications Inc.

[6] Fry, Dennis. 1977. How Did We Learn How to Do It? In Victor Lee (ed.) (pp17-35). Language Development. London: The Open University Press.

[7] Grosjean, Francois \& Ping Li. 2013. The Psycholinguistics of Bilingualism. Oxford: WilleyBlackwell

[8] Holmes, Janet. 2001. An Introduction to Sociolinguistics. London: Longman

[9] Hymes, Dell. 1971. On Commucative Competence. In Victor Lee (Ed.)(pp 3662).Language Development. London: The Open University Press.

[10] Khati, A. R. (2011). When and Why of Mother Tongue Use in English Classrooms. From http://www.nepjol.info/index.php/nelta/article/download/6128/5025

[11] Law of the Republic of Indonesia No. 20 of 2003 concerning the National Education System,

[12] Piaget, Jean. 1972. The Principles of Genetic Epistemology. New York: Basic Books.

[13] Romain, Suzanne. 1989. Bilingualism. Oxford. Blackwell

[14] Salminen, Tapani. 1999. Unesco Red Book On Endangered Languages: Europe. http://www.helsinki.fi/ tasalmin/europe index.html\#state

[15] Suastra, I Made dkk. 2016. Sikap Bahasa Penutur Sasak dan Sumbawa di Bali. Penelitian Grup Riset Hibah PNBP Universitas Udayana

[16] Suastra, I Made, Luh Putu Laksminy, M.Hum, Gede Primahadi Wijaya Rajeg. 2019. Pemerolehan Bahasa Bali dalam Keragaman Bio-Linguistik di Denpasar. Penelitian Grup Reset Hibah PNBP Universitas Udayana.

[17] The Presidential Decree of the Republic of Indonesia No. 63 of 2019 concerning the Use of Indonesian Language.

[18] UNESCO. Ad Hoc Expert group on Endangered Languages. Paris, 10-12 March 2003

[19] Vygotsky, Lev S. 1978. Mind in Society: The Development of Higbe Psychlogical Processes. Cambridge. Harvard University Press.

[20] Weinreich, P. 1986. The operationalisation of identity theory in racial and ethnic relations, in J.Rex and D.Mason (eds). Theories of Race and Ethnic Relations. Cambridge: Cambridge University Press. 